\title{
AN ANALYSIS OF THE PERCEPTIONS OF FATA STUDENTS ON FRONTIER CRIMES REGULATIONS: AN EMPIRICAL STUDY AT HAZARA UNIVERSITY MANSEHRA, PAKISTAN
}

\author{
Dr. Khalil ur Rahman \\ Assistant Professor, Sociology Department, \\ Hazara University, Mansehra \\ khalilskt@gmail.com \\ Tariq Anwar Khan \\ Lecturer, Political Science, \\ Hazara University Mansehra \\ tariqanwar4@yahoo.com \\ Zia Ullah Khan \\ Associate Professor, Political Science, \\ Government Degree College Chakesar, Shangla \\ ziashangla22@gmail.com
}

\begin{abstract}
This study was conducted with an aim to analyze student's perceptions regarding the impact of Frontier Crimes Regulations on the lives of the inhabitants of Federally Administered Tribal Area of Pakistan. Further, the study also aimed at understanding the views of FATA students about the future of Frontier Crimes Regulations. A total of 200 students of Hazara University Mansehra belonging to different Federally Administered Tribal Areas were purposively selected and their responses were taken through structured questionnaires. The collected data was analyzed through descriptive statistics. Findings suggest that Frontier Crime Regulations have a significant and negative impact on the social, legal, cultural and political aspects of the people of Federally Administered Tribal Areas. It is generally concluded that majority of the participants from the area were not satisfied with Frontier Crimes Regulations and thereby demanded that these regulations should be abolished and the regions must be brought under the administration of provincial department.
\end{abstract}

Keywords: Crimes, Tribal; Administration, Regions, Amendments

\section{INTRODUCTION}

Federally Administered Tribal Area (FATA) is spread over an area of 27220 square Kilometer situated along with West by Afghanistan and East-north by the province of Khyber Pakhtunkhwa of Pakistan (Haq, 2008). The area is divided into different political agencies and frontier regions and considered as one of the most strategically important regions in the recent geopolitical scene as well as hold historical significance, because it has been a gateway for various civilizational activities and expeditions for a long period of time (Akbar, 1977). Under the British imperialism, an all-inclusive colonial system had dominated three continents for a period of three centuries. British were the global power, where the sun never set and was the biggest empire in history. After capturing American and African continent, they entered into Asia and sub-continent through East India Company. After consolidating its' position in the subcontinent, they divided British India into two regions as regulatory and non-regulatory areas (Ali, 1997). The imperialist government shaped and executed the obnoxious regulations for non-regulatory areas called as FCR for the governance of FATA in order to achieve their vested interests. The unlawful activities in FATA were considered as a threat to the British imperialism rather than individual crimes (Nichols, 2013). It was a formal manuscript covering rules and penalties for different crimes in tribal areas, which was not only the broad system of supervision, but also chief element of the governnance system (Shah, 2011; Wazir, 2014). 
Numerous studies have been conducted on various aspects of FCR including legal, political and socio-cultural, but Rizvi (2000) described that one of the most detrimental clauses inside the notorious FCR is the concept of "collective responsibility". According to collective responsibility under FCR, sequestration any person short of any legitimate responsibility can prohibit a person from entering into the rest of Pakistan. Bangash (1996) described that the key mistake in FCR is against the fundamental human rights. The tribal people have been denied the fundamental rights of justice under this draconian and black law. Every citizen should be treated an equal citizen before the law with a suitable legal, social and political freedom. Furthermore, in order to control the people of FATA, FCR was formulated under the law of necessity by the British Empire. It describes that one of the notorious practice under FCR is the obnoxious provision which chains everyone in the tribal area for a crime committed by person from his tribe under the term 'collective responsibility'. Additionally, it also reported that the only positive provision in the FCR, according to human rights organization, is that it does not provide death penalty (Afridi, 1993).

Being a set of discriminatory regulations, FCR is specifically viewed as more discriminatory for women, children, teenagers and people of old age. Surprisingly, FCR is also applied to two or three years old children and their mothers. Moreover, women are deprived of their fundamental right of ownership of property and inheritance which render them detach with decision making process at society level as well. It is considered irrational that female get share in retribution in barter or in local terms, 'Badal' or 'Swara' (Bibi, 2005). According to the survey conducted by HRCP (2005) in Kurram, Khyber and Mohmand Agencies of Tribal area regarding FCR, it was highlighted by the participants that "life under FCR is life like slavery in which we can't achieve any progress". Even though the tribal people cannot get a loan for financial activities like other citizens of Pakistan, people sustenance relied on poppy cultivation as any new crops has not been introduced in the area. The right of appeal has also been snatched under FCR and the political agents (PA) act like a dictator, who enjoys an all inclusive political power and status.

A study was conducted in Khyber agency to determine the people attitude towards FCR. The findings have highlighted major flaws within FCRs and there are no proper safeguards of the legal rights of the people. It is an inhumane and injudicious legal system, which promotes the exercise of unchecked and deliberate power by the political administration. FCR is an outdated law which does not meet the needs of the modern age and does not come up to the expectation of the general public. Therefore, it should be abolished or amended to bring an end to unlawful actions against the public in the tribal areas (Alam, 2014).

\section{METHODOLOGY}

This study aimed to empirically investigate the perceptions of FATA students regarding the Frontier Crimes Regulations (FCR). This study was conducted in 2017, when FATA was not merged with the settled districts of the Khyber Pakhtunkhwa province of Pakistan. The study carries immense importance because merging FATA with KPK was a burning issue at that time and it was necessary to empirically examine the views and perceptions of the educated people in order to know the response of well-educated masses regarding FATA status. In this regard, data was collected from 200 students, purposively selected from various academic departments of Hazara University Mansehra, Pakistan. A well-structured closed ended questionnaire was employed which responses range from strongly Agree=1; Agree $=2$; Neutral=3; Disagree $=4$ and Strongly Disagree $=5$. The collected data was analyzed through descriptive statistics and presented in tabulated form. Moreover, Pearson Correlation Coefficient test was employed to find out the public opinion towards FCR.

RESULTS AND DISCUSSION

Table-1. Demographic Information of the Respondents ( $N=200)$

\begin{tabular}{|c|c|c|c|}
\hline \multirow{4}{*}{ Gender } & Attributes & Frequency & Percentage \\
\cline { 2 - 4 } & Male & 168 & 84 \\
\cline { 2 - 4 } & Female & 32 & 16 \\
\hline \multirow{3}{*}{ Age of Respondent } & $20-25$ & 116 & 58 \\
\cline { 2 - 4 } & $26-30$ & 70 & 35 \\
\cline { 2 - 4 } & $31-35$ & 10 & 5 \\
\hline
\end{tabular}




\begin{tabular}{|c|c|c|c|}
\hline & Above 35 & 4 & 2 \\
\hline \multirow{5}{*}{ Agency of Belonging } & Bajaur Agency & 55 & 27.5 \\
\cline { 2 - 4 } & Mohamand Agency & 14 & 7 \\
\cline { 2 - 4 } & Khyber Agency & 32 & 16 \\
\cline { 2 - 4 } & Kurram Agency & 24 & 12 \\
\cline { 2 - 4 } & Orakzai Agency & 15 & 7.5 \\
\cline { 2 - 4 } & North Waziristan & 42 & 21 \\
\cline { 2 - 4 } & South Waziristan & 18 & 9 \\
\hline \multirow{3}{*}{ Educational Qualification } & B.A/BSc & 66 & 33 \\
\cline { 2 - 4 } & MA/MSc & 88 & 44 \\
\cline { 2 - 4 } & M.Phil & 34 & 6 \\
\cline { 2 - 4 } & PhD & 12 & 17 \\
\hline
\end{tabular}

Table-1 shows basic information of the participants. The data revealed that out of the selected 220 respondents, $168(84 \%)$ were male, while $68(16 \%)$ were female. Further, majority being 58\% respondents were from 20-25 years of age, 26-30 years of age were 35\%, whereas, $5 \%$ participants belonged to 30-35 of age group, while $2 \%$ of the respondents were above 35 years of age. The data further revealed that the respondents were belonging to seven political units in which majority of the respondents $(27.5 \%)$ were from Bajaur agency, $7 \%$ in Mohamand, $21 \%$ were from North Waziristan, 9\% from South Waziristan, $12 \%$ to Kurram, $16 \%$ to Khyber, and $7.5 \%$ belonged to Orakzai agency.

Table-2. People's Perception about FCR $(\mathrm{N}=200)$

\begin{tabular}{|l|c|c|c|c|c|}
\hline Statement & SA & A & N & DA & SDA \\
\hline Do you know about FCR & $55(27)$ & $135(67)$ & $10(5)$ & $0(0)$ & $0(0)$ \\
\hline $\begin{array}{l}\text { Do you think that FCR is only } \\
\text { applicable to FATA }\end{array}$ & $20(10)$ & $145(72.5)$ & $20(10)$ & $15(7.5)$ & $0(0)$ \\
\hline In your view, FCR is a century old law & $80(40)$ & $88(44)$ & $20(10)$ & $12(6)$ & $0(0)$ \\
\hline $\begin{array}{l}\text { FCR is better than Pakistan Penal Code } \\
\text { (PPC) }\end{array}$ & $10(5)$ & $28(14)$ & $02(01)$ & $100(50)$ & $60(30)$ \\
\hline
\end{tabular}

Strongly Agree (SA), Agree (A), Neutral (N), Disagree (DA), Strongly Disagree (SDA)

The above table reflects people response towards FCR. The data revealed that $27.5 \%$ respondents were strongly agreed that they know about FCR, whereas $67.5 \%$ moderately agreed that they know about FCR. Furthermore, majority of the respondents being $72.5 \%$ agreed while $10 \%$ strongly agreed that FCR is only applicable to tribal regions. Besides that, $44 \%$ of the respondents were agreed that FCR is a century old system. Furthermore, majority of the respondents being 50\% were disagreed while 30\% strongly disagreed with a statement that FCR is better than PPC.

Table-3. People's Response towards Legal Aspects of FCR $(\mathrm{N}=200)$

\begin{tabular}{|l|c|c|c|c|c|}
\hline Statement & SA & A & N & DA & SDA \\
\hline $\begin{array}{l}\text { Parliament Acts should implement in } \\
\text { FATA }\end{array}$ & $50(27.5)$ & $127(63.5)$ & $23(11.5)$ & $0(0)$ & $0(0)$ \\
\hline $\begin{array}{l}\text { Judicial judgments should extend to } \\
\text { FATA }\end{array}$ & $40(20)$ & $150(75)$ & $08(04)$ & $02(01)$ & $0(0)$ \\
\hline $\begin{array}{l}\text { Under FCR, Political Agent is not } \\
\text { accountable to anyone }\end{array}$ & $08(04)$ & $40(20)$ & $40(20)$ & $98(49)$ & $14(07)$ \\
\hline
\end{tabular}

Strongly Agree (SA), Agree (A), Neutral (N), Disagree (DA), Strongly Disagree (SDA)

Table-3 shows the responses of the participants towards the legal aspects of FCR. The data showed that $27.5 \%$ of the participants were strongly agreed that the act of parliament should be extended to FATA regions, while $63.5 \%$ were agreed, but none of the research participants disagreed 
with the statements. Furthermore, the data show that majority being $75 \%$ of the respondents agreed that judicial judgement should extended to FATA regions, but no respondent disagreed to this statement. It infers that people are willing that their issues must be decided in the higher judiciary rather than decided by local Jirga or political agent under FCRs. The absence of proper and appropriate judicial system produced void of governance in FATA which is filled by militants. They are working beyond the jurisdiction of administration of FATA. The PA is a dictator of old time, he is beyond and over the law. There is no court that his actions are challenged in it. When the respondents were asked about it, $49 \%$ disagreed, while $7 \%$ strongly disagreed with it. So the study findings revealed that there is no proper mechanism that could held PA accountable. Thus the public funds are not appropriately utilized and are being embezzled. The $48.5 \%$ disagreed, while $13 \%$ strongly disagreed when the respondents were asked about that if FCR 2011 reforms help in dispensation of justice in the area.

Table-4. People's Response towards Political Aspects of FCR (N=200)

\begin{tabular}{|l|c|c|c|c|c|}
\hline Statement & SA & A & N & DA & SDA \\
\hline Political Agent is beyond law & $82(41)$ & $64(32)$ & $08(04)$ & $38(19)$ & $08(04)$ \\
\hline Eliminating Corruption & $0(0)$ & $22(11)$ & $77(38.5)$ & $84(42)$ & $17(8.5)$ \\
\hline Reforms in administrative system & $36(18)$ & $30(15)$ & $51(25.5)$ & $64(32)$ & $19(11.5)$ \\
\hline Political environment of the area & $12(06)$ & $122(61)$ & $28(14)$ & $28(14)$ & $10(05)$ \\
\hline
\end{tabular}

Strongly Agree (SA), Agree (A), Neutral (N), Disagree (DA), Strongly Disagree (SDA)

The above table exhibit the responses of participants towards political aspects of FCR. 32\% agreed, while $41 \%$ are strongly disagreed that the PA is beyond the law. PA acts like the ancient kings with obsession of power. Data investigation unveiled that people of FATA are against the dictatorial rule of political agents. The investigation is in accordance with the findings of (Bangash, 1996) that discovered that the concentration of authority in the hands of PA often leads to corruption, misuse of power and injustice. When the respondents were asked if the new reforms in FCR would help in eliminating corruption, $42 \%$ disagreed, while $8.5 \%$ strongly disagreed with the statement because of prevailing brutality, inequality and unfair play by PAs. To a question that if FCR helped in eliminating corruption, $42 \%$ respondents disagreed, and $8.5 \%$ strongly disagreed. Power in the hands of the political agents without proper audit and accountability would not help in eliminating corruption. Data reveals, (Khan, 2012) that the FATA administration is notorious for corruption as there is no proper check and balance. $32 \%$ disagreed, while 11.5 were strongly disagreed, and 25.5 were neutral that the current political and administrative reforms are not satisfactory and it needs overhauling. When the respondents were asked about if the reforms enhanced political awareness among tribal people, $61 \%$ agreed, while $6 \%$ disagreed that these reforms are not sufficient in creating political awareness. Majority of the respondents $(58 \%)$ agreed, whereas $4 \%$ strongly agreed, illuminating 5\% increase from 2008 election, that the overall turnout was $36 \%$ of the total registered voters in FATA in 2013 elections.

Table-5. People's Response towards Social Aspects of FCR (N=200)

\begin{tabular}{|l|c|c|c|c|c|}
\hline Statement & SA & A & N & DA & SDA \\
\hline Role Jirga has significance under FCR & $28(14)$ & $92(46)$ & $08(04)$ & $44(22)$ & $28(14)$ \\
\hline Role and status of women under FCR & $0(0)$ & $32(16)$ & $84(42)$ & $76(38)$ & $08(04)$ \\
\hline The rights of elders, children, and women & $8(04)$ & $58(29)$ & $70(35)$ & $60(30)$ & $4(02)$ \\
\hline
\end{tabular}

Strongly Agree (SA), Agree (A), Neutral (N), Disagree (DA), Strongly Disagree (SDA)

The table indicates the relationship between Jirgah and strong affiliation of tribal people as most of the respondents i.e. $46 \%$ are agreed, while $14 \%$ are strongly agreed about the role of Jirga in dispensation of justice. FCR doesn't provide speedy justice, therefore, people have trust on Jirgah system. Data analysis is consistent with the study of Chaudhry (2011), that the Jirga is playing a conciliatory role when the issues are referred to it by the disputed parties as it is a trusted institution among the tribal people. When the respondents were asked about the role of women in FATA, $42 \%$ 
were neutral while $38 \%$ disagreed with the statement, consistent with the cultural system of the tribal people. The rights of the children, women, and elders under the new FCR reforms 2011 are not satisfactory for majority of respondents. The study of Bibi (2005) deduced that the rights of women and children are at risk in FATA. FCR is helpless to curb such inhuman practices i.e., Swara marriage in which the girls are given in retribution to males as a scapegoat.

Table-6. People Response towards Recent Amendments in FCR (N=200)

\begin{tabular}{|l|c|c|c|c|c|}
\hline Statement & SA & A & N & DA & SDA \\
\hline More amendments must be made in FCR & $10(05)$ & $144(72)$ & $24(12)$ & $12(06)$ & $10(05)$ \\
\hline Are these amendments fruitful? & $24912)$ & $28(14)$ & $30(15)$ & $94(42)$ & $34(17)$ \\
\hline Role of new tribunal of is satisfactory & $04(02)$ & $40(20)$ & $38(19)$ & $102(52)$ & $14(07)$ \\
\hline
\end{tabular}

Strongly Agree (SA), Agree (A), Neutral (N), Disagree (DA), Strongly Disagree (SDA)

The table shows the responses of the study participants about amendments made in FCR. Majority of the respondents agreed, whereas 5\% are strongly agreed that more amendments are needed in FCR. As mentioned earlier that the amendments in FCR in 2011 were termed as historic and life-changing, and such amendements may be continued in the future as well. Regarding the usefulness of the amendments, $42 \%$ respondents disagreed, $17 \%$ are strongly disagreed and not satisfied with the recent amendments. According to the result of Hussain (2012) findings, these new reforms have nothing but old wine in a new bottle, which did not change the existing conditions of the people of FATA. Experts on the study of FATA have categorized these reforms as obsolete because these have not altered anything in the legal, political and social status of the people in the tribal areas. To another question about the FATA Tribunal, majority (52\%) of the respondents were disagreed, whereas 7\% strongly disagreed with the role of FATA Tribunal. Hussain, (2011) findings indicated that the FATA Tribunal is a bureaucratic body, not Appellate or legal body as they recruit bureaucrats rather judges.

Table-7. People' Response towards Implications of FCR ( $\mathbf{N = 2 0 0 )}$

\begin{tabular}{|l|c|c|c|c|c|}
\hline Statement & SA & A & N & DA & SDA \\
\hline Privileges for Maliks and landlords & $30(15)$ & $112(56)$ & $30(15)$ & $20(10)$ & $8(04)$ \\
\hline FCR protects human right & $0(0)$ & $18(09)$ & $50(25)$ & $106(53)$ & $26(13)$ \\
\hline Ratio of Crimes under FCR & $38(19)$ & $76(38)$ & $36(18)$ & $44(22)$ & $6(3)$ \\
\hline Collective responsibility & $10(05)$ & $50(25)$ & $32(16)$ & $108(54)$ & $0(0)$ \\
\hline FCR is a sign of fast justice & $0(0)$ & $46(23)$ & $28(14)$ & $126(63)$ & $0(0)$ \\
\hline FCR may be abolished & $62(31)$ & $132(66)$ & $6(3)$ & $0(0)$ & $(0)$ \\
\hline
\end{tabular}

Strongly Agree (SA), Agree (A), Neutral (N), Disagree (DA), Strongly Disagree (SDA)

The above table highlights the implications of FCR for the people of FATA. The research findings disclosed that only a few people in FATA support the status quo, and the rest are against it, therefore majority (56\%) of the respondents agreed, 15\% participants strongly agreed with a statement that few people are supporting the status quo for their privileged position. The findings of Khan (2005) and Rakistis (2008) are consistent with the current study findings that the FCR has given a privileged position to the landlords at the mercy of larger community. To a question that if FCR protects human rights in FATA, most of the respondents i.e. 53\% disagreed, while 13\% strongly disagreed with it. Study findings corroborate the study of Bangash (1996), that FCR is against human rights because it does not honor women, children and elders. 38\% of the respondents agreed, while $19 \%$ strongly agreed that FCR increase crimes in the area by providing umbrella to criminals. The data findings are consistent with the study of Khan et al, (2008) that the unsafe border from the west has proven to be heaven for crimes and terrorism. To another question that if collective responsibility is a sign of law and order, 54\% disagreed with the statement that it violates fundamental human rights and collective responsibility is not a sign of peace. The question about 
provision of speedy justice by FCR, majority (63\%) of the respondents disagreed that the FCR does not provide swift justice. Furthermore, the people of FATA are suffering from FCR laws as per the responses of majority of the respondents. 66\% agreed and 31.5\% strongly agreed that FCR should be dumped as they have suffered a lot by it. Study investigation is in line with Amnesty International report (2008) that FCR should either be amended or eliminated, so that the people of FATA can enjoy equal rights as other citizens of Pakistan.

Table-8. Relationships between People Perception and Abolition of FCR (N=200)

\begin{tabular}{|l|c|l|}
\hline \multicolumn{1}{|c|}{ FCR } & Pearson Correlation $(\mathbf{r})$ & Sig $(\mathrm{p})$ \\
\hline Legal Aspects & 0.74 & $0.000^{* *}$ \\
\hline Political Aspects & 0.29 & 0.010 \\
\hline Social Aspects & 0.48 & 0.60 \\
\hline Amendments in FCR & 0.66 & 0.007 \\
\hline Implications of FCR & 0.09 & $0.000^{* *}$ \\
\hline Status of FCR & 0.71 & $0.005^{* *}$ \\
\hline
\end{tabular}

**Correlation is significant at 0.005 level of significance

The table shows that there is a significant positive relationship between people perception and legal aspects of FCR (0.000) at 0.005 level of significance. They are clearly supporting the notion that their elected members of parliament should legislate for FATA, and jurisdiction of the judiciary should be extended to FATA. While the absence of former, proper judicial system generated a space of governance in FATA through which political supervision of FATA is working outside their influence. Further, weak and non-significant connection $(r=0.29 ; p=0.001)$ found between people opinion and political aspects of FCR. In the political arena, PA is a dictator because they exercise a blend of judicial and managerial powers against the common masses. While, social aspects have also non-significant $(\mathrm{r}=0.60)$ relationship with FCR, non- substantial consideration should be given to human rights, especially women and children rights.

Moreover, non-significant relationship is seen $(r=0.007)$ in amendments made in FCR as numerous legal and political experts have declared these reforms as absolutely insufficient in the legal and administrative structure of FATA. Similarly, a weak significant relationship ( $r=0.000)$ was found between people perception and implications of FCR. That only few and wealthy people like, political agents and Maliks (notables) got benefits from it, while rest of the natives are drastically exploited. For that, people want to abolish FCR, and significant relationship was found ( $r=0.005)$, that FCR should be abolished with provision of constitutional and human rights guarantees to the people of tribal area.

\section{CONCLUSION}

The people of FATA have been suffering since long by the cruelty of FCR, even after 115 years. In the light of current findings and analysis of this research, the British Government planned FCR for their vested interest as was observed that the respondents were fully familiar with it. But, it is noteworthy that the state could neither applicably bring positive changes in the judicial and administrative set up of FATA nor entirely integrated it after the independence of Pakistan, which spread over a long political journey. Unfortunately, all fundamental rights of the modern age are absent in FCR, right is a fundamental entitlement, which a person claims against the government. The seizure of assets and arrest of an individual without any proper legal process is against human rights. Most critical clause known as collective responsibility is most vicious of all clauses of FCR. The court of law denies the right of appeal for the people of FATA as given by the constitution of Pakistan to present reasoned evidence. It is worth mentioning that the FATA parliamentarians have the legislative authority to legislate for the rest of Pakistan, but not for FATA, as acts of parliament have no jurisdiction over FATA. It is also astonishing that it consists of senior bureaucrats instead of judges, while FATA Tribunal is regarded as an appellate body. Jirga plays a vital role in the settlement of disputes, but its selection is at the disposal of the PA. Political Agent is highly authoritative office and behaves like a dictator. The integration of FATA into the mainstream politics is a dream for the people of tribal people as recent amendments made in FCR, appreciated by 
different quarters, does not fulfill the wishes of the general public. This study concluded that majority of the people have suffered from the injustices caused by FCR, therefore they strongly recommended that it should be put to an end, and they should be granted and treated as the citizens of Pakistan. Therefore, it was suggested that FATA should be integrated into the Khyber Pakhtunkhwa province of Pakistan as all these FATA regions are geographically contagion to the province. Through merging of the FATA region into KPK province, the public may enjoy the benefits and privileges of the mainstream political, legal and administrative systems of Pakistan.

\section{REFERENCES}

Afridi, L. (1993). Human Rights and Discriminatory Laws in FATA" in the Frontier Post, Peshawar Akbar, A. (1977). Social and Economic Change in the Tribal Areas. Oxford University Press.

Alam, I., Muhammad, N., \& Shah, M. (2014). Frontier Crimes Regulation (FCR) and Writ of the State: A Study on Local People's Perception in Khyber Agency. Pakistan Journal of Criminology, 6(1), 305-315.

Ali, K. (1977). A New History of Indo-Pakistan, Since 1526. Aziz Publishers.

Bangash, M. A. (1996). Political and Administrative Development of Tribal Area: A Focus on Khyber and Kurram (Unpublished Ph.D. Thesis, Area Study Centre, Peshawar University).

Bibi, M. (2005). Women and children's rights under the FCR; paper read in seminar on "A bad law nobody can defend" which was organized by Human Rights Commission of Pakistan.' 2005: pp 10; Qasim Karim Printers, Lahore

Chaudhry, G.M. (2011). Summary of 2011 Amendments to the Frontier Crimes Regulation. Retrieved from: http://www.FATAreforms.org/summary-of-2011-amendments-tothefrontier-crimes-regulation/

Haq, N., Khan, R.A., \& Nuri, M.H. (2005). Federally administered tribal areas of Pakistan (No. 10). Islamabad Policy Research Institute. Retrieved from: http://hrcpweb.org/publication/book/fcr/ Socio-political Assessment of the Frontier Crimes Regulation

Hussain, F. (2011). The judicial system of Pakistan. Supreme Court of Pakistan.

Hussain, M.H. (2012). Frontier Crimes Regulation: A Case study of reforms process. TIGAH: A Journal of Peace and Development, 2(1), 122-132.

Khan, I., Cheema, P.I., \& Wirsing, R.G. (2005). Challenges Facing Pakistan's Federally Administered Tribal Areas (FATA). National Bureau of Asian Research.

Khan, M.A. (2012). Social, political and economic implications of Frontier Crimes Regulation (FCRs) in FATA, Pakistan. Asian Journal of Social Sciences \& Humanities, 3(1), 250-261.

Nichols, R. (Ed.). (2013). The Frontier Crimes Regulation: A History in Documents. Oxford University Press.

Rakisits, C. (2008). Pakistan's Tribal Areas: A Critical No-Man's Land. Identity and Conflict, $127(1), 1-10$

Rizvi, H. A. (2000). Military, State, and Society in Pakistan. New York: Martin's Press.

Shah, S.W.A. (2012). Political reforms in the Federally Administered Tribal Areas (FATA) of Pakistan: Will it End the Current Militancy? South Asian \& Comparative Politics, 64(1), 118.

Wazir, A.K., \& Khan, M.Z. (2014). Mainstreaming FATA through legal and political reforms. A Journal of Peace and Development, 4(4), 25-48. 